\title{
New approaches to the Third World Church*
}

Prof H. Dewaard

\section{INTRODUCTION :}

This topic seems straightforward. Many would translate it simply: What can we (Western churches) do for the churches on the mission field? Such an attitude would betray our ignorance of the real issues involved in relating to the churches of the Third World. Actually this is an extremely complicated and very sensitive issue which has kept pens and tongues moving for decades already and many missionaries have felt in body and soul the difficulty of this relationship. Missionaries sent out by a western church in order to convert the "heathen" when arriving on the "field" find that there is a church there, capable of evangelizing its own people. The missionary must work under the control and direction of the Third Church or, should he not ie prepared to do so, he will be ignored and join the large number of the frustrated!

In this article I hope it will become clear why this topic is so complex and why the missionary is going through a crisis of identity. Times have changed rapidly. Politically the Third World is coming to its own as a force to be reckoned with. The Third Church is becoming a vocal and legitimate and mature partner. Many Western Christians however, still live in the colonial age and have not been able to assume a wholesome attitude to the Third Church.

\section{THIRD WORLD AND THIRD CHURCH}

These terms are very ambiguous and can be given different meanings. Hence the need to clarify this terminology.

In the 1950's "Third World" referred to a "third force" of non-aligned nations, non-industrialized, underdeveloped countries of Asia, Africa and Latin-America in contrast to the capitalistic forces of the NATO nations (1st world) and the communist-aligned nations of the Warsaw Pact (2nd world). More recently, the poor and oppressed, especially racial and ethnic minorities in the US and Europe, have also been included as belonging to the Third World.

I am using Third World here as a shorthand term to refer to a set of societies sharing common characteristics, namely, the societies of Asia, Africa and Latin America.

The church in these countries will be referred to as the "Third Church" (a term coined by W. Buhlmann); the First Church being the Eastern Orthodox Church, the Second Church being the Church of the West, (both Catholic and Protestant) and the Third Church that of the Third World. That this church needs to be taken seriously is emphasized by Buhlmann:

* Hierdie artikel het in Vox Reformata, Nov. 1987 verskyn en word met vergunning van die outeur geplaas. 
We are in the middle of a process of change as a result of which the church at home in the western world for almost 2000 years will, in a short time, have shifted its centre of gravity into the Third World . . . (1977:20).

The term "Third Church" has no derogatory connotation such as is implied in the term "third class", "third rank" or "third rate"! It expresses that in the historical development of the Christian movement, a new expression of the church has emerged alongside expressions of the church that already existed.

For obvious reasons I will deal here with the relationship between the Western Church and the Third Church, and posit the thesis that these two churches need each other:

The Third Church must not remain a kindergarten for mother church nor a poor house for the exercise of her charity ... The Third needs the Second for support and the Second needs the Third for renewal (Bühlmann, 1977:23).

The constant complaint from the Third World is that the Second Church seems to have no need of the Third Church and that the theology of the Second Church is not always relevant to the needs of the Third Church.

Let me quote an African scholar:

It is utterly scandalous for so many Christian scholars in older Christendom to know so much about heretical movements in the second and third centuries, when so few of them know anything about Christian movements in areas of the younger churches. We feel deeply affronted and wonder whether it is more meaningful theologically to have academic fellowship with heretics long dead than with the living brethren of the Church today in the so-called Third World (Mbiti, 1976:17).

There can be little doubt that between the Second and Third Church there is spiritual and theological alienation. Hence the need for partnership in the real sense of the term.

\section{BIBLICAL-EXEGETICAL DATA IN APPROACHING THE THIRD CHURCH}

One image of the church in the NT is "body of Christ." This term is used without the definite article to indicate that the church is never the body of Christ. Local churches are seen as a manifestation of the one, universal church. In the local church, the new people of God is represented. In I Corinthians 12, Paul points to the interdependence of the members, who are dependent and responsible for each other. This same mutual dependence and fellowship (in the knowledge and salvation given in Christ) is expressed in the images of a household and brotherhood (1 Peter $2: 7,5: 9 ;$ Eph $2: 19$ ). The church is bound together by an underlying essential Gospel which binds the members together (Rom 1:1, Col 1:26. Acts $28: 31$, I Cor $15: 1-3$ ). Fellowship between members and between churches is in truth (Gal $1: 8,9)$. Over against attempts at syncretism in the Colossian church, which wanted to worship "the powers," Paul emphasized the all-sufficiency of Christ. The interdependence and mutuality between individual members must also be realized in the relationship between congregations. They are not only to help each other 
to exist but to enhance the total functioning of the whole body (I Cor 12:26, 27).

This mutuality between churches comes to very concrete expression in the aid given by the church of Antioch to Jerusalem (Acts $11: 27-30$ ) and the collection organized by Paul in the churches of Asia Minor and Greece for the poor in Jerusalem (I Cor $16: 1$ - 3, II Cor $8: 9$, Rom $15: 25$ 27. Gal 2: 10) (Jansen Schoonhoven, 1977:20 - 33).

\section{Antioch's aid to Jerusalem}

This aid was occasioned by the visit of prophets from Jerusalem who prophesied the spread of a famine. The church in Antioch decided to collect funds and send this collection to Jerusalem by means of Paul and Barnabas.

Never before had heathens given the hand of fellowship to Jews and called them brothers (Acts 11:29). The gap between Israel and the goyim was always large. This time it was bridged (Jansen Schoonhoven, 1977:21).

\section{Paul's collection for the poor in Jerusalem}

Throughout his ministry in Asia Minor, Paul had given much attention to the poor among the saints at Jerusalem (Rom $15: 26$ ). This was in accordance with the charge given him by the leaders in Jerusalem, when they acknowledged his ministry among the heathen. (Gal $2: 10$ - only they would have us remember the poor, which very thing I was eager to do.)

At the end of the third missionary journey, Paul wanted to present the collection personally to the apostles, accompanied by representatives of the churches in Asia Minor and Greece. We don't know what happened to the collection. Luke does not record the handling over of the collection to the church in Jerusalem.

Paul apparently saw the danger of estrangement between the Hebrew Christians in the diaspora. This was one of the reasons for organizing assistance. The Gentiles had shared in the spiritual blessings of the Jews (Rom $15: 27$ ). There is an element of "exchange," but the "goods" exchanged need not to be of the same kind. Financial aid is not necessarily a sign of ecclesiastical imperialism! It might just as well become a sign of inner and universal fellowship.

At least we can conclude that Western churches ought to be concerned about the poverty and needs of the Third Church and the Third Church must be concerned about the secularism of the West. Relationships of the past (old-young, mother-daughter) are no longer valid. Relationships must now be seen in the context of Body of Christ. Today, more than ever before, it is possible to express the interdependence of churches throughout the world.

\section{OBSTACLES THAT DISCOURAGE PARTNERSHIP BETWEEN CHURCHES}

In order to appreciate the complexity of approaching the Third Church, let me enumerate some of the obstacles that impede healthy relationships.

a. Relationships were (and are) often paternalistic. Financial aid has frequently been used as a means to dominate. This fact has bred resent- 
ment on the part of the Third Church. The Third Church feels dependent and therefore powerless.

b. European peoples (like most other peoples) have a deeply ingrained feeling of their own superiority. Representatives of Western European civilization were the ones who introduced Christianity into the Third World complete with its European trimmings. Missionaries have often (unintentionally) conveyed a superior attitude which has caused serious tensions. In this light we must view the call for a moratorium, the rise of independent churches and cargo cults, the development of African, Asian and other Third World theologies. The danger of theological nationalism is very real.

c. Missions to the majority of Christians still means the going of Western Christians into the non-Christian world. However, after the second World War we have increasingly recognized that the non-Christian world is not geographically defined. Hence the call for mission in six continents and the concept of missions as two-way traffic.

d. Today, mission has tended to become identical with inter-church aid and transfer of money and personnel to weak Third Churches. This is not partnership. Nor is the presence of personnel always desired: (Jansen Schoonhoven, 1977:85). This situation must be borne by missionaries as a result of past mistakes. "It is not possible to inherit the glory of the past without also paying for its mistakes!"

e. The Third Church has often overreacted in order to assert its independence. Situations arise in which the Western church is only allowed to provide funds without having any say in the use, administration and distribution of funds. Or, the Third Church will not have missionaries working in its territory with the argument that they themselves are responsible for the evangelization of their own people.

f. The Third Church knows very little about the Second Church and vice versa. Usually relationships are maintained by mission bodies of the Western Church with the hierarchy of the Third Church.

g. We cannot speak of mature relationships when partners are not open to mutual criticism. A guilt-complex on the part of Western Christians has enabled them to cope well with criticism from the Third Church. However, criticism of the Third Church by Western Christians is a very sensitive sisue which may well lead to a breakdown in relationships. The missionary as disturber is not tolerated.

$h$. The transplantation of denominationalism has guaranteed the dependence of the Third Church on the West. Each denomination wants its own seminary, offices, printing press and therefore needs funds from the Western "mother" church. Many churches in the Third World have closer ties with the "mother denomination" than with churches in their own area.

\section{THE DEVELOPMENT OF THE CONCEPT OF MUTUALITY}

It may be helpful in thinking about the approaches to the Third Church to trace the development of the concept of mutuality between churches. I 
do so by referring to the international missionary conferences held since the beginning of this century.

Edinburgh - 1910 hardly touched on the question of mutual relationships. The relationship between "old" and "young" churches was still a matter for the future - " . . an organized church in the mission field is no longer only an idea, but is now clearly in view as an actual church in being" (Jansen Schoonhoven, 1977:35). V. S. Azaraiah from India pleaded: "Give us friends!" (Bosch, 1978:285).

Jerusalem 1928 made many references to partnership, equality, cooperation. For the first time there was reference to Third Churches sending missionaries to the West.

St. Paul heard the voice from Europe: come over and help us. Now the old Christian fellowship in its turn says to the missionary communions: come and help us make our faith and the experience of the One, Holy, Catholic and Apostolic Church real and active on earth! We fully realize that great difficulties are at stake in the new churches as well as in old historic Christendom. We need each other. But before all we need Christ (Soderblom, 1928).

Tambaran 1938 was preoccupied with the relationship of Christianity over against non-Christian religions.

Whitby 1947 was a very important conference for the development of mutual relationships. Whitby coined the term "partnership in obedience." This slogan reflected the changed and changing world situation in which colonialism was ready to be laid to rest! Whitby was very optimistic about creating new relationships, though fully aware of the practical problems. (An Indonesian commenting on the slogan: For you the partnership, for us the obedience!).

Willingen 1952 met under the theme "Missions under the Cross." Willingen experienced the shadow cast by the missionary debacle in China. Now that the mission of the church seemed to have failed, all the emphasis was being placed on the missio dei to which the mission ecclesiae is subordinate.

Ghana 1958 expressed some of the complexities of partnership in obedience. It was at this conference that Freytag said: The Mission used to have problems, now mission is itself a problem! At this conference the cry: Missionary, go home! began to be heard and Western churches began to ask themselves whether younger churches wanted to limit the Western contribution to pay and pray.

Mexico City 1963 coined the concept "Mission in Six Continents" and "Joint Action for Mission." No longer was the world divided in a Christian and non-Christian part.

Bangkok 1973 took place after all the violence and turbulence of the sixties. Third World churches became more vocal about their own identity. They refused the Frankfurt Declaration of $P$. Beyerhaus, because it is a basically Western document. The relationship between churches should be marked by maturity. "Basic to such a relationship is mutual commitment to participate in Christ's mission in the world."

Melbourne 1980. At this conference the influence of Liberation Theology was clearly evident. Only one section dealt specifically with mission: 
"The Church's Witness to the Kingdom." Other sections while allegedly dealing with missionary themes, actually spoke to the pressing needs of the Third World. These themes were: "Good News to the Poor," "The Kingdom of God and Human Struggles" and socio-political issues such as poverty, exploitation, justice and power.

Thus we see how the existential concerns of the Third Church began to dominate the agenda.

Partnership in obedience is very difficult to realize due to patterns of paternalism and power structures that have been established for many years. Against this background we must see the call for a moratorium, launched in the early 1970's.

According to Verkuyl, the call for a moratorium (that is, a temporary suspension in the sending of personnel and financial aid) must be seen against the background of paternalistic structures that disparage Third World cultures and of the activity of many faith-missions that do not take local churches into account in determining strategy (1975:452 - 459). To illustrate the depth of alienation that has occured (and still occurs) between the Second and Third Church, let met quote two prominent Asian leaders:

The most missionary service a missionary can do today for Asia is to go home (Nacpil, Philippines).

The mission of the church is the greatest enemy of the Gospel (Verghese, India) (Bosch, 1978:287).

It seems that the Western Church has remained captive to a donor mentality, while the Third Church continues to be dependent and so fails to develop its potential because of a receiver mentality.

In the meantime the call for a moratorium has been modified considerably and is rarely heard now. However this does not mean that the root problem has been solved.

It does not mean however, that the Western Church has been made more aware of the problem and greater efforts will be made toward the establishment of more truly mutual relationships. In this the Western Church is aided by the increasing realization that it is also in a minority position and that it lives in a missionary situation.

Moreover, there is also an increasing appreciation of the pluriformity of the church which in turn has engendered greater appreciation for the church in the Third World, which may have as much to give to the Western Church as the Western Church has to give to the Third Church. The self-sufficiency of the Western Church is in the process of being broken down. Before long, there will be an openness and ability to receive. This calls for the realization that each church cannot give the same "commodity" but each can contribute and so complement the needs of the other.

\section{TOWARDS TRUE COMPLEMENTARITY}

In this section I would like to indicate how the Second and the Third Church could initiate and develop approaches toward each other in order to come to genuine partnership. First, I would draw attention to areas where the Second Church could assist the Third Church. Second, I would 
like to suggest some areas of cooperative effort and lastly the contribution the Third can make to the Second Church.

A. Areas of assistance:

1. Stimulating local leadership, for example, through the provision of scholarship if necessary. In this connection we think of Paul's method (advocated by Roland Allen in his Missionary Methods: St. Paul's or Ours of entrusting local congregations to local leadership. In many areas of the Third Church leadership is in local hands but the training of local leadership needs to be an ongoing process.

2. Sending of personnel. In some countries this is no longer possible. But in others it is still necessary, though usually only highly qualified personnel are acceptable and allowed to work.

The presence of overseas personnel is not without its difficulties and raises far-reaching problems. Many missionaries have experienced the difficulty of living and working in a culture so different from their own.

3. Short-term workers. In certain areas short-term workers would be valuable, especially in the case of transference of technical knowhow. However, in areas of work where knowledge of country, culture, language and personal relationships are required, the short-term worker is a liability!

4. Financial aid for scholarships, pensions, salaries for evangelists. This is a very sensitive issue and churches must be careful when committing themselves to long-range programs. However, there is a genuine financial need in many Third Churches. Often, personnel are invited, for the Third Church has already learned that "money follows the man ..."

The danger with financial commitments is that money is power and may easily lead to manipulation and domination. This is what a prominent Latin-American theologian has to say:

You have to learn to renounce resources as a means of domination. In order to do this you must learn to lose control over what you give. Our temptation is that of the poor - the temptation to sell ourselves. Your temptation is that of the rich - to become masters (MiguezBonino, 1974:46).

On the other hand, we do have silver and gold and are therefore responsible to the Third World!

B. Areas of common effort

1. The spiritual care of overseas students. There are thousands of students from the Third World in every Western Country. Churches from the Third World should be invited to take part in the care of these students in dispersion.

2. The presence of guest laborers and migrants from the Third World is another area where cooperation between the Second and Third church could be realized. There are sizable groups of Turks, Egyptians, Filipinos, Chinese etc. in Australia. It would be very difficult for Australian churches to give adequate attention to these ethnic groups. The Third Church must be called in to assist. 
3. Exchange of guest lecturers. In Western theological colleges more efforts should be made to know the churches of the Third World and their theological concerns and vice versa. Lecturers from Third Churches are needed and Western Churches might do well to have some ministers from the Third Church. The presence of western personnel in the Third Church is already an established fact.

4. Perhaps the area of international tourism is still an unexplored field. After spending some time in Bali and seeing the large numbers of tourists and especially Australians, I wondered whether the Australian churches do not have a responsibility here together with the church in Indonesia. For the thousands of tourists there is little provision in the way of spiritual care.

5. Exchange of fraternal delegates, not only for Synodical meetings, but also for extended visits would be valuable.

C. Gifts from the Third Church

I have already referred to the fact that mutuality does not mean that each must give the same commodity, rather each must complement the needs and ministries of the other.

What can the Third Church contribute? I suggest the following:

1. The Third Church has provided the impetus for the ecumenical movement. Without the Third Church, the Western Church would be very much isolated and introverted. We need the Third Church to remind us constantly of the universal scope of the Gospel and the impossibility of a uniform expression of the Christian faith.

2. The Third Church has opened the eyes of the Second Church to the role of the lay person. Lacking the financial resources to have many full-time pastors, the Third Church has had to rely on the spiritual gifts of the whole congregation.

3. The Third Church can teach us how to live as a Christian minority in pagan surroundings. The church in the West is becoming a minority group and no longer privileged as in the past. This raises a whole lot of new issues in which the Third Church may assist, for the Third Church has never been but a small minority (with some exceptions).

4. The Third Church can also be a reminder for the Second Church about the need for conversion. In Western theology the need for conversion is increasingly questioned. Many are now saying that it is the task of the church to make Muslims better Muslims etc. and that each can be saved within the context of his own religious tradition. No definite break is required in order to become Christian. The Third Church which is still facing the challenge of great growth can help the Western Church understand that the "new birth" is essential for entrance into the Kingdom of God.

5. The Third Church can help us develop and adopt a new, Christian, simpler life-style. In that way the Church may become more credible in a world of poverty and starvation. The new life-style must be one less attached to "things," more meditative, coupled with a belief in the intervention of God in our human history. 
6. The Third Church living in a totally different cultural context can draw our attention to many neglected theological issues and to new understandings of the Scriptures eg liberation, evil, survival and community.

The above are just a few concerns I can think of. No doubt there are more. I wonder, however, to what extent the Western Church is really prepared to listen to and learn from the Third Church?

\section{BIBLIOGRAPHY}

Anderson, G. H. and Stransky, T. F., eds. Mission Trends No. 1. New York and Grand Rapids: Paulist Press and Eerdmans, 1974.

Bosch, D. J. "Toward True Mutuality: Exchanging the same Commodities or Supplementing Each Other's Nieeds," Missiology, Vol. VI, No. 3, p. 283 - 296, 1978.

Buhlmann, W. The Coming of the Third Church. New York: Orbis Books, 1977

Jansen Schoonhoven, E. Wederkerige Assistentie van Kerken in Missionair Perspectief. Leiden: Interuniversitair Instituut voor Missiologie en Oecumenica, 1977.

Mbiti, John S. "Theological Impotence and the Universality of the Church," Mission Trends No. 3, Anderson and Stransky (eds). New York, Grand Rapids: Paulist Press, Eerdmans, p. 6 - 18.1976.

Miguez Bonino. "The Present Crisis in Mission," Mission Trends No. 1, Anderson and Stransky (eds) New York, Grand Rapids: Paulist Press, Eerdmans, 1975, p. 37 - 48.

Verkuyl, J. Inleiding in de Nieuwere Zendingswetenschap. Kampen: Kok, 1975. 